Bu makaleye atıfta bulunmak için/To cite this article:

ERDOĞAN, Z. (2021). Alman Sığınma Sisteminde Açık Kapıdan Entegrasyon Siyasetine Geçiş ve Tolerans

Politikası. Atatürk Üniversitesi Sosyal Bilimler Enstitüsü Dergisi, 25 (Özel Sayı), 65-86.

\title{
Alman Sığınma Sisteminde Açık Kapıdan Entegrasyon Siyasetine Geçiş ve Tolerans Politikası
}

\section{Zahide ERDOĞAN ${ }^{(*)}$}

Öz: Almanya 2015-2016 yıllarında "açık kapı politikası” uygulayacağını ve Dublin Düzenlemelerini asklya aldı̆̆ını açılklayarak 1 milyondan fazla mülteciyi kabul etmiştir. Almanya cömert bir mülteci politikast ve "entegrasyon siyaseti" uygulamasına rağmen çoğu siğınmacıya mülteci statüsü vermemiştir. Bu politika, Almanya'nın çok fazla mülteci alıp almadiğı, yük paylaşımı, mültecilerin güvenlik riski ve tehdit olup olmadığı sorularını ortaya çıkarmıştır. Almanya hızlıca politikasını değiş̧tirmiş ve sınırlayıcı sı̆̆ınma politikaları uygulamaya başlamıştır. Alman sığınma sisteminde dört tür koruma bulunmaktadır: Mülteci, sığınmacı, ek koruma ve sinır dışı etmenin yasaklanması (Tolerans-Duldung). Bu makale, 2015 yllindan itibaren sı̆̆ınmacı sayısını kısıtlamaya yönelik uygulamaların çerçevesini oluşturmayı, entegrasyon siyaseti ve tolerans statüsünün değişimini incelemeyi amaçlamaktadır. Başvurusu reddedilen sı̆̆ınmacıların eğitim, çalışma, sağlık gibi belirli koşulları karşılamaları halinde ülkede kalmasına (tolerans) izin verilmekle birlikte tolerans statüsü hala geçici, belirsiz ve entegrasyonu engelleyen bir statüdür. Diğer taraftan, son değisiklikler tolerans statüsündeki kișilerin entegre olma potansiyellerini (hak etme) göstermeleri halinde entegrasyonuna ve Almanya'da sürekli kalma imkanına sahip olmalarına olanak sağlamaktadır.

Anahtar Kelimeler: Alman siğınma sistemi, tolerans-duldung, entegrasyon siyaseti, göç yönetimi, uluslararası göç

\section{From Open-Door to Integration Politics and Toleration Policy in Germany's Asylum System}

Abstract: Germany accepted over 1 million refugees in 2015-2016 by announcing an "opendoor refugee policy" and suspension of the Dublin Regulation. Although Germany adopted a generous welcome policy and "integration politics", many asylum seekers were not granted refugee status. This policy has raised the questions of whether Germany has received too many refugees, burden sharing, whether refugees pose a security risk and a threat. Germany quickly changed its policy and started to implement restrictive asylum policies. The German asylum system has four forms of protection: refugee, asylum, subsidiary protection, and a ban on deportation (toleration-Duldung). This paper aims to prepare a framework of implementations from 2015 and to examine transformation on integration politics and toleration status. Rejected asylum seekers may be granted a tolerated stay under certain circumstances such as education, work, and health issues but toleration status is still temporary, uncertain, and hinder integration. On the other hand, the latest amendments facilitate the integration of people in toleration status who demonstrate the potential to integrate (deserving) and have a chance of staying permanently in Germany.

\footnotetext{
*) Dr., Kültür ve Turizm Bakanlığı Yurtdışı Türkler ve Akraba Topluluklar Başkanlığı, (e-posta: zahide.rdgn@gmail.com), (D) ORCID ID. https://orcid.org/0000-0002-0253-9355

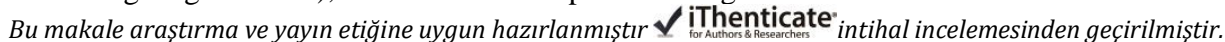


Keywords: Germany asylum system, toleration-duldung, integration politics, migration management, international migration

Makale Gelis Tarihi: 01.03.2021

Makale Kabul Tarihi: 02.11.2021

DOI: 10.53487/ataunisosbil.889011

\section{Giriş}

Ülkeler için uluslararası göçün yönetimi dinamik bir alan olup, yalnızca uluslararası sorumluluklardan değil $\mathrm{AB}$ üyesi ülkeler için $\mathrm{AB}$ mevzuatından, iç siyasetten, dış politikadan, ülkenin ekonomik ve demografik yapısından etkilenmektedir. Uluslararası göç, "kişilerin köken ülkelerinden veya mutat ikametgâhlarından sürekli veya geçici olarak başka bir ülkede kendi yaşamlarını kurmak amacıyla hareketleridir. Bunun sonucunda bir uluslararası sınır geçilmesi” olarak tanımlamaktadır (IOM, 2004: 33). 2019 yılı itibariyle uluslararası göçmen sayısı 272 milyona ulaşmış olup, bu rakamın yaklaşık 82 milyonu Avrupa ülkelerinde yaşamaktadır (United Nations, Department of Economic and Social Affairs Population Division, 2019: iv). Zorunlu olarak yerinden edilen 79,5 milyon kişinin 26 milyonu mülteci, 4,2 milyonu sığınmacı ve 45,7 milyonu ise ülke içinde yerinden edilmiştir (UNHCR, 2020: 2). 2019 yılı itibariyle Suriye'de başlayan olaylar sonrası 6,6 milyon Suriyeli ülkelerini terk ederek mülteci-sığınmac1 ${ }^{1}$ olmuştur (UNHCR, 2020: 8). 2011 yılında Suriye'de başlayan iç karışıklıklar sonrası Suriyeli sığınmacıların büyük bir kısmı Türkiye, Lübnan, Ürdün gibi komşu ülkelere sığınırken 2015 yılı ve sonrasında sığınmacılar Avrupa ülkelerine de yönelmeye başlamış ve Avrupa mülteci (sığınmacı) krizi ile karşılaşmıştır. Mülteci krizine üye ülkeler farklı şekillerde cevap vermiş, genellikle Doğu Avrupa ülkelerinde mültecileri almayı reddeden din merkezli mülteci politikaları uygulanmaya başlarken (Karakoç Dora: 2020) Almanya'nın çok sayıda mülteciyi kabul etmesi ve cömert hoş geldin yaklaşımı dikkat çekmiştir. Diğer taraftan, AB üyesi ülkelerin sı̆̆ınmacı girişini azaltmayı amaçlayan önlemlerinin dışında AB düzeyinde de önlemler alınmıştır. Türkiye ve $A B$ arasında 2013 yılında imzalanan ve 1 Ekim 2014 tarihinde üçüncü ülke vatandaşlarına ilişkin hükümleri hariç yürürlüğe giren Geri Kabul Anlaşması, 1 Haziran 2016 itibariyle tüm hükümleriyle yürürlüğe girmiştir. Ayrıca, özellikle üye ülkelerle birlikte çalışan FRONTEX'in yasadışı sığınmacı girişini engellemek amacıyla AB'nin temel değerleri arasında yer alan insan haklarını ihlal edecek biçimde sert önlemlerle operasyon yürütmesi hem medya hem de sivil toplum kuruluşlarının eleştirilerine konu olmuştur (Üstün, 2021: 396).

Almanya, göçmen ülkesi olmaktan ziyade işçi kabul eden bir ülke olarak bilinmektedir. İkinci Dünya Savaşı'ndan sonra Batı Almanya'ya (Federal Almanya) mülteciler ve sürgün edilenlerle birlikte işçi ihtiyacı nedeniyle "misafir işçiler" de göç etmeye başlamış ve 2005 yılında kabul edilen Göç Yasası ile Almanya'nın göçmen ülkesi olduğu kabul edilirken göç politikaları da reform edilmiştir (Gesley, 2017: 1).

\footnotetext{
${ }^{1}$ Mülteci-sı ğınmacı: Makalenin konusu olan Federal Almanya'da, sığınma politikası kapsamında mülteci ve sığınmacı statülerine tanınan haklar birbirinden farklıdır. Bu nedenle bazı kısımlarda mülteci-sığınmacı ifadesi birlikte kullanılmıştır.
} 
Özellikle 1960’lı yıllarda işçi anlaşmaları ile Türkiye, İtalya gibi ülkelerden Almanya'ya göç edenlerin geçici ve ülkelerine dönecek gruplar olarak görülmesi bu fikri pekiş̧irmiştir. Ancak daha sonra iş̧i olarak gidenler geri dönmemiş, aile birleşimi yolu ile ailelerini yanlarına almışlar ve artık geçicilikten kalıcılığa adım atılmıştır. 2019 yılsonu itibariyle nüfusu 83,2 milyon olan Almanya'da, göçmen kökenli kişi sayısı 21,2 milyon olup, bu rakam nüfusun \%26'sını oluşturmaktadır (Federal Statistical Office, 2020). Bu çerçevede başlangıçta misafir işçi kabul eden Almanya artık bir göçmen ülkesidir.

Almanya'nın 2015 yılında 1.000 .000 mülteciyi alacağına ilişkin açılaması ile birlikte artan sığınmacı-mülteci sayısı, ülke içinde güvenlik, yük ve mülteci sayısına ilişkin tartı̧̧maları beraberinde getirirken Almanya bu şekilde "hoş geldin kültürü" ve "entegrasyon siyasetini” benimsemiştir (Funk, 2016: 289). Almanya'da koruma arayan kişi sayısı 2010 yılında 500.000 iken Suriye'deki olayların etkisiyle 2013 yılından itibaren artarak 613.925 'e yükselmiş, özellikle mülteci akımının Avrupa'ya yöneldiği 2014-2015 yıllarından itibaren ise önemli ölçüde artış göstermiş ve toplam koruma arayan kişi sayısı 2019 yılında 1.839.115'e ulaşmışırı (Tablo 1). 2010 yılında geçici statü verilen kişilerin toplam koruma arayanlara oran $\% 33$ olup, bu oran 2016 yılına kadar benzer şekilde sürmüştür. 2016 yllında $\% 38$ olan geçici statü verilenlerin oranı 2017 yılında \%53, 2018 yllında \%57 ve 2019 yilında \%59 olarak gerçekleşmiştir. Bununla birlikte sürekli statü verilen kişi sayısının toplam koruma arayanlara oranı ise 2010 yllında \%43 iken 2019 yllında bu oran \%15'e düşmüştür (Tablo 1). Dolayısıyla, geçici statü verilen kişi sayısında oransal olarak önemli bir artış görülürken sürekli statü verilen kişi sayısı oransal olarak azalmışıtır.

Tablo 1: Almanya'da koruma statüsüne göre dağılım (2010-2019)

\begin{tabular}{|l|c|c|c|c|c|}
\hline Yıl & Yerleştirilmeyenler & $\begin{array}{c}\text { Geçici statü } \\
\text { verilenler }\end{array}$ & $\begin{array}{c}\text { Sürekli } \\
\text { statü } \\
\text { verilenler }\end{array}$ & Reddedilenler & $\begin{array}{c}\text { Toplam } \\
\text { koruma } \\
\text { arayan kişi } \\
\text { sayısı }\end{array}$ \\
\hline $\mathbf{2 0 1 0}$ & 35.835 & 168.205 & 214.115 & 85.310 & 503.470 \\
\hline $\mathbf{2 0 1 1}$ & 47.130 & 151.045 & 222.825 & 84.920 & 505.925 \\
\hline $\mathbf{2 0 1 2}$ & 65.920 & 165.610 & 233.440 & 84.860 & 549.825 \\
\hline $\mathbf{2 0 1 3}$ & 110.335 & 174.110 & 236.460 & 93.020 & 613.925 \\
\hline $\mathbf{2 0 1 4}$ & 177.900 & 208.460 & 251.675 & 108.280 & 746.320 \\
\hline $\mathbf{2 0 1 5}$ & 349.810 & 285.805 & 262.130 & 138.495 & 1.036 .235 \\
\hline $\mathbf{2 0 1 6}$ & 574.945 & 599.235 & 268.265 & 155.120 & 1.597 .570 \\
\hline $\mathbf{2 0 1 7}$ & 348.640 & 888.355 & 266.010 & 177.700 & 1.680 .700 \\
\hline $\mathbf{2 0 1 8}$ & 306.095 & 1.017 .760 & 265.465 & 192.430 & 1.781 .750 \\
\hline $\mathbf{2 0 1 9}$ & 266.470 & 1.090 .475 & 269.590 & 212.575 & 1.839 .115 \\
\hline
\end{tabular}

Kaynak:https://www.destatis.de/EN/Themes/SocietyEnvironment/Population/Migration -Integration/Tables/protection-time-series-protections-status.html (19.01.2021).

Zorunlu olarak yerinden edilerek ülke sınırını geçen kişilerin tümü yasal olarak mülteci kabul edilmemektedir. Bu noktada kimin mülteci olduğuna ilişkin verilecek karar mülteci statüsünün getireceği haklara sahip olmayı da sağlayacaktır. Dolayısıyla, 
mülteci statüsü bir tür ödül ve zor elde edilen bir etiket olup, dışlanmayı vatandaş ve "diğerleri” arasındaki ayrımı meşrulaştıran ve açığa çıkaran bir statüdür (Zetter, 2007). Alman sığınma sisteminde mülteci statüsü ile birlikte sığınma hakkı, ek koruma ve sınır dışı etmenin yasaklanması yoluyla verilen tolerans belgesi ile edinilen statü gibi farklı haklarla tanımlanan koruma biçimleri yer almaktadır. Tolerans statüsünün Bosnalı sığınmacılar üzerinde belirsizlik nedeniyle travma etkisi oluşturması ile insan hakları yaklaşımı arasındaki paradoksa (Dimova, 2006), bu statüde bulunan Filistinli mültecilerin çalışma, eğitim ve seyahatlerinin kısıtlanması ile sürekli sınır dışı edilme tehdidi altında bulunmalarına (Tize, 2020) ve Federal Almanya'nın Afgan sığınmacıları iyi entegre olmuş olmalarına rağmen sınır dışı etmesine (Sökefeld, 2019) yönelik çeşitli araştırmalar bulunmaktadır. Diğer taraftan, 2015 yılındaki açık kapı politikası ile sığınmacılar için uygulanan entegrasyon programlarına ilişkin çalışmalar (Bird, 2015; Gesley, 2016; Konle-Seidl, 2018) da mevcuttur. Ancak, 2015 ve sonrası sığınmacilara ilişkin düzenlemelerin kategorize edildiği bir çalışmaya rastlanmamıştır.

Bu makale, Alman sığınma sisteminde 2015 sonrası mülteci krizi ile birlikte sığınmacı sayısını azaltmaya yönelik önlemlerin kavramsal çerçevesini oluşturmayı, entegrasyon siyaseti ve tolerans statüsünün değişimini incelemeyi amaçlamaktadır. Çalışmada, 2015 sonrası göçle ilgili yasal düzenlemelerden hareket edilmiştir. Çalışmanın sığınmacı ve mültecilerle çalışan akademisyenler ve uygulayıcılar için entegrasyon-sınır yönetimi-yasal statü konusunda bir çerçeve oluşturması hedeflenmiştir. $\mathrm{Bu}$ çerçevede makalenin birinci kısmında tarihsel bakış açısından hareketle Almanya'ya yönelen mülteci-sığınmacı hareketleri ele alınarak tolerans statüsünün tarihsel izleri araştırılmışıı. İkinci kısımda Almanya sığınma sisteminde tolerans statüsünün özellikleri ve bu statünün verilmesine ilişkin kriterler tartışılmıştır. Üçüncü kısımda ise 2015 yllında başlayan "hoş geldin kültürü" ve "entegrasyon siyaseti”" ile açık kapı politikasının sınırlayıcı politikalara dönüşmesi kapsamında alınan önlemler, tolerans statüsünde olanların entegrasyon içine dahil edilmesi ve "hak etme"3 yaklaşımına odaklanılmıştır.

\section{Tarihsel Çerçeve}

Almanya 1918-1933 yılları arasında Weimar Cumhuriyeti döneminde yasal olarak mültecileri kabul etmiş, 1929 tarihli Sınır Dışı Yasasıyla sınır dı̧̧ı etme yasaklanmış, 1932 Polis Düzenlemesiyle siyasi mültecilere sığınma hakkı verilmesi kabul edilmiş, ancak 1933'te Nazi rejimi ile birlikte sığınma hakkına karşı çıkılmış, yüzbinlerce kişi sürgün edilmiştir (Hanewinkel \& Oltmer, 2018). Batı Almanya (Federal Almanya), 1951 Mültecilerin Hukuki Statüsüne İlişkin Sözleşme (1951 Mülteci Sözleşmesi) ve 1967 tarihli Protokolü imzalamıştır (Hanewinkel \& Oltmer, 2018).

\footnotetext{
${ }^{2}$ Entegrasyon siyaseti ifadesi Funk, N. (2016). A spectre in Germany: Refugees, a 'welcome culture' and an 'integration politics'. Journal of Global Ethics, 12(3), 289-299 makalesinden hareketle kullanılmıştır.

${ }^{3}$ Hak etme ifadesi Deserving-ness, Sökefeld, M. (2019). Nations Rebound: German Politics of Deporting Afghans. IQAS, 50(1-2), 91-118 makalesinden hareketle kullanılmıştır.
} 
Alman Sığınma Sisteminde Açık Kapıdan Entegrasyon Siyasetine Geçiş ve Tolerans Politikası

Ülkelerin mültecilere ilişkin politikaları tarihteki mülteci hareketlerinden etkilenmektedir. Almanya I. Dünya savaşından itibaren çok sayıda mültecinin sığındığı bir ülkedir. 1917-1920 yılları arasında Bolșevik Devriminden kaçan Rus mültecilerin 600.000'i 1922-1923 yılına kadar Almanya'da yaşarken yetersiz entegrasyon politikaları ve ekonomik-yasal destek olmaması nedeniyle ülkeyi terk etmiş ve 1927 'de bu sayı 150.000'e kadar düşmüştür (Bierbach, 2018). Doğu Avrupa'da aynı dönemde Yahudilere uygulanan zulüm sebebiyle kaçan 90.000 Yahudi yine Almanya'ya sığınmış, ancak 1933-1945 yılları arasında Nazi rejimi döneminde Almanya'da yaşayan 500.000'den fazla Yahudi ülkeden kaçmıştır (Bierbach, 2018). Dolayısıyla, Almanya bir taraftan mülteci kabul eden bir sığınma ülkesi iken diğer taraftan mülteci kaynağı olan bir ülkedir.

II. Dünya Savaşıyla birlikte Avrupa haritasının yeniden çizilmesi zorunlu yerinden edilmelere yol açmıştır. Alman topraklarının bir kısmının Rusya, Polonya, Litvanya, Çek Cumhuriyeti gibi ülkelerin eline geçmesiyle yaklaşık 12 milyon kişi yerinden edilmişsir (Bierbach, 2018). Yaklaşık 3,6 milyon kişi Sovyetlerin işgalindeki Doğu Almanya'ya gitmiş, Federal Almanya'nın 1949 yılında kuruluşuyla 1961 yılında Berlin Duvarı inşa edilene kadar yaklaşık 3,5 milyon kişi Doğu ve Batı Almanya arasında göç etmiştir (European Migration Network, 2010: 21). II. Dünya Savaşı sonrası iki Almanya'nın bölünmesi üzerine pek çok kişinin etnik Alman olmakla birlikte başka topraklarda kalması ve Doğu Almanya'nın mültecilere karşı yaklaşımı Batı Almanya toplumunun mülteci ve sığınmacılara ilişkin olarak yeni bir yaklaşım benimsemesine yol açmıştır (Poutrus, 2014: 118). Bu yaklaşım değișimi Anayasa'da da görülmektedir. 1949 Anayasası "politik sebeplerle zulme uğrayan kişiler sığınma hakkından faydalanmalıdır" ifadesini içermekte olup, bu kapsamda olduğu kabul edilen kişilere Federal Almanya'da çalışma, sosyal haklar gibi konularda vatandaşlarla aynı haklar sağlanmıştır (Poutrus, 2014: 117). Stokes'e göre (2019: 21-22), Federal Alman Anayasası dünyadaki en cömert sığınma garantisini sağlamakla birlikte "politik sebeplerle zulüm" kavramının ne olduğu sorusunu cevapsız bırakmıştır. Bugünkü sığınma rejiminin kökenleri anayasada yer alan siyasi sığınma çerçevesinde şekillenmiştir.

Almanya'nın sığınmacı ülke olarak önemi 1949-1968 arası sığınan kişi sayısının az olması nedeniyle sınırlı kalmış, genellikle ülkeye sığınanlar Doğu, Merkezi, Güney Avrupa ülkelerinden gelenler olduğundan bu durum ülkenin mülteci politikasının antikomünist yaklaşıma dayandığı şeklinde yorumlanmıştır (Oltmer, 2016: 27). 1956 yılında Macar mülteciler, 1968'de Çek Cumhuriyetinden kaçan mülteciler, 1973'te Şili'den kaçanlar olmak üzere genellikle komünist veya sosyalist ülkelerden kaçan siyasi sığınmacılarla birlikte Doğu Almanya'dan kaçanlar da Batı Almanya'ya sığınmışıır (Bierbach, 2018). 1963 yllında Almanya'daki yeni sığınma taleplerinin \%91’i Yugoslavya'dan gelmiş, Hallstein Doktrini çerçevesinde 1955 yılından beri Doğu Almanya ve tanıdığ şartlarını taşımayanlar sınır dışı edilememiş, bu durum "ekonomik mülteci” kavramının ortaya çıkmasına yol açmışıı (Stokes, 2019: 32). Dolayısıyla, Almanya o tarihlerde de 
ekonomik nedenlerle göç eden ancak sığınma konusunu kullanan ve sığınmacı-mülteci olma şartlarını taşımayanları sınır dışı edememiş veya etmemiştir.

Abraham'a (2016: 5) göre, sınırların kontrolü, ülkeye gireceklerin ve sınır dış1 edileceklerin belirlenmesi, bazı hallerde anayasal sınırlamalara tabi olmakla birlikte, eşitlik ve anayasada yer alan sınırlamalardan ziyade aslında dış politika tercihlerinin bir göstergesidir. 1958 yılında Cezayir-Fransa Savaşı sırasında, Fransa'dan Batı Almanya'ya sığınan Cezayirliler bu olayın bir örneğidir. Cezayirli mülteciler olayı, Fransız Hükümeti ile ilişkilerle Anayasadaki sığınma hakkı arasındaki çelişkiyi belirginleştirmiş, bu grup nedeniyle halkın siyasi mültecileri kabul etme isteği ile devletin savunma yaklaşımı arasında ortaya çıkan çelişki 1965 Yasasına da yansımıştır (Poutrus, 2014: 127). 1965 tarihli Yabancılar Yasası çerçevesinde 16 yaşından küçük çocuklar, mülteciler ve yerinden edilen yabancılar ikamet izninden muaf tutulmuş, 5 yıl Almanya'da yaşayan ve entegre olan yabancıların sınırsız ikamet iznine başvurabilmeleri ve sığınma hakkı verilenlere yasal ikamet izni hakkı tanınmıştır (Gesley, 2017: 5). Söz konusu yasa, başvurusu reddedilen sığınmacılar için istisnai bir düzenlemeyle sınır dışı edilmelerini engelleyen bir tür ikamet izni sağlamış, prosedürlerin uzunluğu ve zulme uğrama kriterlerinin belirlenmesi sorunu devam etmiş̧tir (Poutrus, 2014: 128). Böylece, Cezayirli mülteciler olayında öne çıkan siyasi gerginliği ortadan kaldırabilecek mekanizma, Yugoslavya'dan gelen "ekonomik mültecilerin" sınır dışı edilememesinde benzer şekilde sınır dışı etmenin engellenmesiyle kurulmuştur ve bu şekilde sığınmacılarla ilgili konularda belirli bir hareket serbestisi de sağlanmıştır. Almanya sınır dışı etme ya da etmeme kararları ile uluslararası sorumluluklarıyla beraber ülkelerle ilişkilerini de korumuştur.

Mülteciler dışında Almanya'nın işçi göçü almaya başlaması, iş gücü ihtiyacını karşılayan yeni bir kaynak olarak ortaya çıkmıştır. II. Dünya Savaşından sonra ortaya çıkan işçi ihtiyacını karşılamak amacıyla 1955 yılından ekonomik resesyonun başladığı 1973 yilına kadar Türkiye, İtalya, İspanya, Portekiz, Fas ve Tunus gibi ülkelerle imzalanan işçi anlaşmaları ile belirlenen sürelerin sonunda işçilerin ülkelerine geri dönmelerini esas alan "rotasyon" prensibi çerçevesinde misafir işçiler Almanya'ya gelmeye başlamıştır (Gesley, 2017: 4). Bu dönemde Almanya, mülteci krizini çözmeye çalışıken, 1961 'de Berlin Duvarının inşası Doğu-Batı Almanya arasındaki günlük işçi geliş gidişini engellemiştir (Stokes, 2019: 31). Almanya'nın iş̧̧i göçü alan ülke olmaya başladığı bu dönemde mülteci akımları da devam etmiştir. 1973 yılından itibaren misafir işçi alımını durduran ve çalışma izni vermeyen Almanya'ya tekrar sığınmacı akımı başlamıştır. 1950-1970 arası dönemde mülteci göçü Avrupa merkezli sürerken, 19701980'li yıllarda Vietnam Savaşından kaçan mülteciler, Polonya, Türkiye ve İran'dan kaçanların Almanya'ya sığınması ile ülke Avrupa dışından da sığınmacılarla karşılaşmaya başlamıştır (Oltmer, 2016: 27).

Bu dönemde Türkiye'den gelen sığınmacıların çoğu ekonomik sığınma olarak görülmüş ve bu tür sığınmayı engellemek amaciyla vize yükümlülüğü ve 4 yıl süreli çalışma yasağı uygulaması başlatılmış, bu tür önlemler sığınmacı talebinde azalma sağlarken entegrasyonun gecikmesi sorunu ortaya çıkmıştır (Stokes, 2019: 37). 1980’li yıllardan itibaren misafir işçilerin geri dönüşleri ile ilgili düzenlemeler yapılmaya 
başlanmıştır. 1983 yılında kabul edilen Geri Dönüş Yardımı Yasası ile Avrupa Ekonomik Bölgesi (EEC) dışından gelen işyerlerinin kapanması veya iflası nedeniyle işsiz kalan, Alman vatandaşı ile evli olmayan misafir işçilere ülkelerine geri dönmeleri halinde 10.500 Alman Markı geri dönüş yardımı yapılması öngörülmüştür (Gesley, 2017: 6). Böylece geri dönüşlerin teşviki uygulaması da başlamıştır.1987'den itibaren Doğu Avrupa'daki etnik Almanların Federal Almanya'ya dönmesi insan kaynağ1 ihtiyacını azaltmış, sı ğınmacı girişini azaltmak için sınır kontrolleri artırılmış ve sığınma sisteminin suistimal edildiği fikri öne çıkmaya başlamıştır (Oltmer, 2016: 28).

1990’lı yıllarda Doğu blokundan gelen etnik Alman sığınmacıların sayısının 397.073'e ulaşması siyasi baskı oluşturmuş, Yugoslavya'nın dağılması ile Federal Almanya'ya sığınanların sayısı artmış, etnik Almanların bile dönüşü için yıllık kota uygulaması başlatılmıştır (Stokes, 2019: 41-42). 1990’lı yıllar Federal Almanya açısından hem sığınmacı sayısının azaltılmaya çalışıldığı hem de 1960'lı yıllardaki işçi göçü ile gelen göçmenlerin ve ailelerinin haklarına ilişkin olarak düzenlemelerin yapıldı ğı bir dönem olmuştur. 1990 yılında kabul edilen Yabancılar Yasasıyla ikinci nesil göçmenlerin aile birleşimi, vatandaşlık ve çocukların vatandaşlığ düzenlenmiş, 1992 yılında sığınmacı sayısı 440.000'e ulaşmış, 1992 Yasası ile gerçekten siyasi sebeplerle zulme uğrayanların sığınmacı olarak kabulü ve güvenli üçüncü ülkeden ${ }^{4}$ gelenlerin sığınma taleplerinin reddi düzenlenmiştir (Gesley, 2017: 7-8). 1993 Yasası, "sığınma tavizi” olarak bilinmekte olup, söz konusu düzenleme Anayasada yer alan sığınma hakkını önemli ölçüde sınırlandırmaktadır. Düzenleme AB ülkesi veya üçüncü ülkeden giriş yapan sığınmacıların taleplerinin reddini gerektirmekte olup, Almanya tümüyle AB-Schengen ülkelerine komşu olduğundan hava ve deniz yolu ile gelenlerin sığınma hakkı bulunmaktadır (Hanewinkel \& Oltmer, 2018). Bu dönemde sığınma sisteminin kötüye kullanımı ve artan sığınmacı sayısı azaltılmaya çalışılırken sınır dışı etmenin ertelenmesi-tolerans (Duldung) statüsü ortaya çıkmıştır. Geçici mülteci statüleri ve çok sayıda kişinin bazen 25 yıla ulaşan uzun sürelerle "Duldung" statüsünde kalması Almanya’nın durumunu özelleştirmektedir (Tize, 2020: 4). Tolerans statüsü, sığınmacı olma koşullarını sağlamayanların ya da ülkede vizesiz ya da ikamet izni olmadan bulunanların belirli durumlarda geçici olarak sınır dışı edilmesini engelleyen, süresi ve gelecekte ne olacağı belirsiz bir statü olarak ortaya çıkmıştır.

2005 yılında yürürlüğe giren yasayla Almanya'nın göç politikalarında önemli değişiklikler meydana gelmiş olup, iş piyasası $\mathrm{AB}$ dişından gelen göçmenlere de açılırken nitelikli işgücü göçünü teşvik eden düzenlemelerle entegrasyon konusu da yasaya girmiştir. Söz konusu düzenleme ile AB dışından gelen göçmenlerin mevsimsel işler ve geçici kontratlarla çalışmalarına imkan tanımak yoluyla iş piyasası göçmenlere açılırken, nitelikli göçmenler ve en az 1 milyon Avro yatırım yapmak koşuluyla yeni

\footnotetext{
${ }^{4}$ Güvenli Üçüncü Ülke: Almanya'ya $\mathrm{AB}$ ülkelerinden veya komşu başka bir ülkeden giriş yapanlar ile "güvenli köken ülke" listesinde olan ülkelerden gelenlerin sı̆̆ınma talepleri de kabul edilmez (Gesley, 2016: 8-9).
} 
istihdam oluşturacak girişimlerin gelişine izin verilmiştir (Gräßler, 2005). Aynı zamanda bu yasayla ilk kez Federal Yasaya entegrasyon konusu girmiş ve entegrasyon hem Federal hem de yerel düzeyde bir görev olarak düzenlenmiștir (Federal Office for Migration and Refugees, 2015: 27). Özellikle bilgi işlem sektöründe iş gücü eksikliğinin gidermek amacıyla, 2005 Yasasıyla yüksek nitelikli kişiler için uzun dönemli ikamet izni, entegrasyon, "geçici" ve "sürekli" ikamet izinleri olmak üzere ikamet türlerinin azaltılmas1, "Talep ve Destek" prensibi (Fördern und Fordern) gibi konular düzenlenmiştir (Gesley, 2017: 9-10). Ayrıca bu dönemde konuya verilen önemin bir göstergesi de entegrasyondan sorumlu olan "Entegrasyon Başkanı"nın doğrudan kabine ile bağlantısının sağlanarak pozisyonun güçlendirilmesidir (European Migration Network, 2010: 28).

2005 yılından itibaren Almanya'nın göçmen ülkesi olarak kabul edildiği ilk defa entegrasyona da yer verilmesinden görülmektedir. Bu dönemde entegrasyonla ilgili çalışmalar AB'den gelen fonlarla desteklenen projelerin yanı sıra 2006'da Müslümanların Alman toplumuna katılımını ve entegrasyon bazlı projeleri desteklemek amaciyla Alman İslam Konferansının kurulması, 2007'de ise Entegrasyon Ulusal Eylem Planının hazırlanması ile sürmüştür (Federal Office for Migration and Refugees, 2015: 29-30). Almanya bu şekilde proje destekleri ve kurumsal işbirlikleri yoluyla entegrasyon konusunda çalışmaları yoğunlaştırmıştır. Ancak, başlangıçta entegrasyon projelerinden ve desteklerinden herkesin değil yalnızca belirli statülere sahip olanların yararlanmasını öngören sınırlayıcı entegrasyon yaklaşımı ise 2015 sonrası değişerek sadece statü değil belirli kriterleri karşılayanların entegrasyonuna doğru gelişmiştir.

\section{Sığınma Sistemi ve Tolerans-Duldung Statüsü}

1951 Mülteci Sözleşmesine göre mülteci, “....rk1, dini, tabiiyeti, belirli bir sosyal gruba mensubiyeti veya siyasi düşüncesi nedeniyle zulme uğrayacağından haklı sebeplerle korktuğu..." (UNHCR, 2010: 14) için sınırı geçerek başka bir ülkede uluslararası koruma arayan kişi olup, mültecilerin hakları söz konusu Sözleşme ile korunmuştur. 1951 Mülteci Sözleşmesinin 33. maddesinde sığınmacılar için "geri gönderme" yasağı yer almaktadır. Sığınmacı ise mülteci statüsü almayı bekleyen ancak başvurusu henüz karara bağlanmamış, başvuru sonucunun olumsuz olması halinde insani koruma ya da benzeri bir koruma ile kalmasına izin verilmediği durumlarda ülkeyi terk etmesi gereken kişidir (IOM, 2004: 8). İnsan Hakları Evrensel beyannamesinin 14(1) maddesinde "Herkes zulüm karşısında diğer ülkelerden sığınma ve sığınma olanaklarından yararlanma istemek hakkına sahiptir" ve 15. maddesinde ise "Herkes uyrukluk hakkına sahiptir" ifadesi yer almaktadır (Universal Declaration of Human Rights, 1948). Diğer taraftan sığınma hakkı, Avrupa Birliği Temel Haklar Şartının 18. maddesi ile korunmakta olup, Dublin Düzenlemesi ile sığınma taleplerinin değerlendirilmesinde ülkelerin sorumlulukları belirlenmiştir. Almanya'da ise sığınma ve mültecilerle ilgili düzenlemeler başta Anayasa olmak üzere çeşitli yasal metinlerde yer almaktadır.

Almanya'da mülteci statüsünün elde edilmesi üç tür program kapsamında olabilmektedir. Bunlar; Almanya' ya giriş yaptıktan sonra ülke içinde sığınma talebinde bulunmak ve aile birleşimi, insani kabul programları ve gerek ulusal olarak ilan edilen 
gerekse AB tarafindan belirlenen yeniden yerleştirme suretiyle kabul programlarıdır. İnsani programlar kapsamında kırılgan gruplar ile durumu riskli kişilere belirli kotalarla koruma sağlanmakta olup, 2009-2010 y1llarında Almanya 2.501 Iraklı mülteciyi, 20132015 arasında 40.000 Suriyeliyi kabul etmiş, ancak bu kapsamdaki kişilere sadece geçici koruma statüsü verilmektedir (Korntheuer, 2017: 38). Yeniden yerleştirme, "uluslararas1 koruma arayan kişinin onu kabul edecek üçüncü ülkeye sürekli ikamet statüsü ile naklini, AB düzeyinde UNHCR'ın talebi ile uluslararası koruma arayan üçüncü ülke vatandaşının ulusal mevzuat ve $\mathrm{AB}$ mevzuatına göre mülteci statüsü, ek koruma gibi bir koruma verebilecek üye devlete naklini” ifade etmektedir (EMN, 2018: 326). AB tarafından yürütülen yeniden yerleştirme programları dışında Almanya'nın kendi ulusal yerleştirme programı da bulunmakta, ancak ulusal program kapsamında çok az sayıda (300-500 kişi) kişi kabul edilmektedir (Korntheuer, 2017: 38). Diğer taraftan, Kanada ve Birleşik Krallık'ta uygulanan sponsorluk Almanya'da da bulunmaktadır.

Almanya'da sığınma sistemi farklı koruma türlerini içerecek şekilde düzenlenmiştir. Sığınma talepleri Federal Ofis tarafından değerlendirilmekte olup, sığınma hakkı (Anayasa madde 16a), mülteci koruması (Sığınma Yasası Bölüm 3), ek koruma (Sığınma Yasası Bölüm 4) ve sınır dışı etmenin yasaklanması (İkamet Yasası 60 V ve VII) olmak üzere 4 tür koruma kararı söz konusu olmaktadır (Federal Office for Migration and Refugees, 2019: 21-25):

$\checkmark$ Sığınma hakkı, anayasa ile tanınan bir hak olup, bu kapsamda sığınmacılar 3 yıl süreyle ikamet izni, iş piyasasına erişim hakkı ve aile birleşim hakkına sahiptir.

$\checkmark 1951$ Mülteci Sözleşmesi çerçevesinde mülteci olarak kabul edilenleri kapsayan mülteci koruması ile mültecilere 3 yıl ikamet izni, 3 yıl veya 5 yıldan sonra yerleşme izni, iş piyasasına erişim ve aile birleşimi talep etme hakkı verilmektedir.

$\checkmark$ Ek koruma ise köken ülkede ölüm cezası, işkence gibi ciddi zarar görme riski altında olanlara sağlanır ve bu statüde olanlar 1 yıl ikamet izni, 5 yıldan sonra yerleşme izni, iş piyasasına erişim hakkına sahip olmasına rağmen aile birleşimi isteme hakkı bulunmamaktadır.

$\checkmark$ Kişinin ülkesine geri dönüşü risk oluşturuyorsa, hayati risk, özgürlüklere ilişkin veya sağlık için somut tehlike söz konusu ise kişiye sınır dışı edilmesinin yasaklanması-ertelenmesi statüsü verilebilir. Bu statü ile tekrar uzatılabilir 1 yıl ikamet hakkı, koşulları sağlamaları halinde 5 yıldan sonra yerleşme hakkı ve ilgili idarenin izni ile çalışma hakkı tanınmaktadır.

Tolerans statüsünün verilmesi belirli koşullara bağlanmıştır. İltica başvurusu reddedilenlerle, vize veya oturum izni olmadan ülkeye girenlerin iltica talebinde bulunmasalar da ülkeyi terk etmeleri gerekmekte olup, aşağıdaki koşulları sağlayanlara tolerans (Müsamaha-Duldung-Toleration-Tolerated Stay) belgesi verilebilmektedir (Handbook Germany, 2020a): 
- Yasal ya da fiili nedenlerle sınır dışı edilememe: Örneğin pasaportun olmaması, sağlık sorunları, uçuş olmaması.

- İnsani ve kişisel nedenler: Örneğin, tedavi, eğitim, hasta aile üyesine bakma.

- Kamuyu ilgilendiren bir nedenle kalma.

- En az iki yıl sürecek mesleki eğitime başlama durumu (eğitim Duldung)

- Belirli süre çalışmak, dil gibi koşulları yerine getirme (çalışma Duldung).

- Ülke bazlı sınır dışı etme yasağı uygulanması (60a).

Sığınma başvurusu reddedilen kişilerin köken ülkeye dönüşü genellikle mümkün olmadığından ülkeler farklı uygulamalarla bu süreçte bazı esneklikler tanıyabilmekte ve "insani”" ya da "tamamlayıcı" düzenlemelerle sığınma başvurusu reddedilen kişilerin de belirli sürelerle ülkede kalmasına izin verilmektedir (European Migration Network, 2010: 36). Geçici bir statü olan tolerans statüsü diğer yasal statülere başvurma imkanı vermeyen, köken ülkenin güvenli olarak kabulü halinde geri dönüş gerektiren ve çalışma hakk1, seyahat, yükseköğretim veya entegrasyon kurslarına katılma hakkı sunmayan, seyahat özgürlüğünün sınırlı olduğu bir statüdür (Tize, 2020: 4). Ancak, bu statüde olanlara belirli süre ülkede kalmaları halinde bazı imkanlar sunulmaktadır. Örneğin; söz konusu statüdeki kişiler başka bir yerde barınma imkanı yoksa barınma merkezlerinde kalabilir, 3 ay yasal olarak ya da sınır dışı etmenin ertelenmesi nedeniyle ülkede kalan kişiler çalışabilir, 15 aydan fazla bu şekilde kalanlar için iş piyasasında öncelik kontrolü uygulanmaz, sığınmacı başvurusu reddedilenler sı̆̆ınmacı yardımlarından ve bu sürenin 15 ayı geçmesi halinde sosyal yardımlardan faydalanabilir (EMN, 2016: 23-24). Dolayısıyla, tolerans statüsünde olanların ülkede kalış süreleri arttıkça belirli yardımlardan ve uygulamalardan yararlanmalarına imkan tanıyarak dolaylı da olsa entegrasyonun kolaylaştırılması söz konusudur. Diğer taraftan bu statü, 1951 Mülteci Sözleşmesinde yer alan geri gönderme yasağının bir tür uygulaması olarak geçici süreli de olsa ülkede yasal olarak kalmanın bir yöntemi olarak görülebilir.

Almanya'nın geri dönüş politikası yalnızca reddedilen sığınmacılar için değil ülkede kalışları yasal olmayan herkes için aynı olup, sığınma talepleri reddedilenlere özel bir düzenleme bulunmamaktadır (EMN, 2016: 29). Tolerans politikası kişilere verilen geçici ikamet belgesiyle (Aufenthaltsgestattung) ülkede sadece belirli bir süre daha kalma hakkı vermekte (Handbook Germany, 2020b) olup, sınır dış1 etmenin geçici olarak ertelenmesidir, kişilere verilen belge ikamet izni olmayıp kişinin hala ülkeyi terk etme yükümlülüğü bulunmaktadır (EMN, 2016: 22). 2020 yılı yarıyıl raporuna göre, ülkeyi terk etmesi gereken 271.767 kişiden 220.907 'si tolerans statüsünde ve 50.860 ' 1 ise tolerans statüsünde olmayan kişi olup, toplam rakamın 173.208 'i sınır dışı edilmiş ve sınır dışı edilenlerin ise 148.840'ı tolerans statüsündedir (Abschiebungen und Ausreisen im ersten Halbjahr 2020, 2020: 53). Ayrıca, söz konusu politika ile ülkede geçici olarak kalacak kişiler de süreli olarak verilen belgelerle kontrol altında tutulmaktadır.

Almanya açısından yasadışı göçmenlerin "tolere" edilmesi yeni olmayıp, 19501960 'lı yıllarda da siyasi mültecilerin yanı sira ekonomik nedenlerle ülkeye girenler de bir şekilde "tolere" edilmişti. 1990'lı yıllar Yugoslavya'nın dağılması ile birlikte sığınmacı sayısının Avrupa'da hızlı arttı̆̆ 1 ve ekonomik göçmenler ile sığınmacıları ayırabilmek için kısıtlamaların hayata geçirildiği bir dönem olmuştur. Bosna ve Kosova 
Savaşları nedeniyle AB ülkeleri II. Dünya Savaşından sonra ilk defa bu kadar büyük kitlesel göç olayı ile karşılaşmıştır. Bu nedenle AB Üyesi devletlerin Göç Bakanları'nın Londra'da yapılan toplantısı sonrasında eski Yugoslavya'dan kaçanlara geçici koruma sağlamayı kabul eden bir karar yayınlanmıștır. Üye devletler geçici koruma sağlamayı kabul etmekle birlikte, devletler söz konusu kişilerin sığınmacı prosedürlerine ulaşmalarını sağlamak zorunda değildir, ülkeler söz konusu kişilerin güvenli bir şekilde geri dönüşleri sağlanana kadar geçici koruma sağlama konusunda ellerinden geleni yapacaklarını bildirmiştir (Bunyan, 1997: 73-73). Daha sonra AB 2001 yılında, üye ülkeler arasındaki uygulama farklılıklarını gidermek amacıyla üçüncü ülkelerde yerinden edilen ve köken ülkeye dönme imkanı olmayan kişiler için kitlesel göçte uygulanacak Geçici Koruma Direktifini kabul etmiştir (EU Immigration and Asylum Law, 2001). Ülkede bu dönemde sınır dışı etmeler artarken "tolerans sığınmacıları 'tehdit' ederek büyük akışı düzenleme aracı olmuştur."(Tize, 2020: 4). Bosna Savaşı sırasında diğer Avrupa ülkeleri sığınmacılara ikamet izni ve çalışma izni verirken Almanya Bosnalı sığınmacıları "Duldung" olarak kabul etmiş ve söz konusu kişilerin sınır dışı edilmesi bu sayede geçici olarak durdurulmuştur (Kirchhoff \& Lorenz, 2018: 52). Bosna savaşından kaçan kişiler 1951 Mülteci Sözleşmesine göre mülteci ya da Alman Anayasasına göre sığınmacı olarak kabul edilmemiş ancak ülkeden sınır dışı edilmeleri de mümkün olmadığından geçici bir çözüm olan tolerans statüsü verilmiştir. Dolayısıyla, geri gönderme yasağına da pratikte uyulmuştur.

"Tolerans" politikası her ne kadar AB'nin baskıları sonucu uygulansa da Almanya 1992'de 438.000 sığınmacı sayısına ulaşan tek ülkedir ve bu politika için kullanılan "Ketten-Duldung" kelimesi bu politikanın "güvensiz", "uzun dönemli" ve "sonu olmayan bir statü" olduğunu göstermektedir (Tize, 2020: 4). Tolerans statüsü bir taraftan sınır dışı edilmeyi engelleyerek insani koruma sağlamakta, diğer taraftan ise sınırlı haklar ve geçici süre nedeniyle sığınma talep eden kişi için belirsizliği getiren ve entegrasyonu kısmen engelleyen bir statü olarak karşımıza çıkmaktadır. Aslında tolerans statüsü entegrasyon desteklerinden yararlanmayı belli süre engellemekte olup, kişilerin belirli süre sonra çalışmaları ya da kendi çabaları ile dil öğrenmelerini engelleyen bir düzenleme yoktur.

Diğer taraftan, bazı dönemlerde bu statüde olan kişi sayısını azaltmak ve iş piyasasına entegre etmek amacıyla düzenlemeler de yapılmıştır. İki Almanya'nın birleşmesinden sonra tolerans statü düzenlemesi muhafaza edilmiş, 1990'lı y1llarda tolerans statüsü verilen 170.000 kişinin yaklaşık 50.000'ine, 1 Temmuz 2007 itibariyle belirli süre ülkede ikamet edenlere geçici ikamet hakkı ve suç kaydı olmayan, ekonomik yeterlilik, Alman toplumuna entegre olmak, çocukların okula devam etmeleri gibi koşulları yerine getirenlere ise sürekli ikamet izni verilmiştir (Leise, 2007). Halen tolerans statüsünde olanlardan insani sebeplerle, nitelikli iş gücünün en az 2 yıl sürekli çalışıyor olması, gençlerin entegre olması ve en az 8 yıldır yaşayanların daimi entegrasyonu hallerinde dil bilme, yardım almama, suç işlememe gibi koşullarla ikamet izni verilerek bu statüden çıkmaları ve ülkede kalışlarının yasal hale gelmesi mümkündür (EMN, 2016: 25-27). Bu 
tür düzenlemelerle ülkeden sınır dışı edilmesi geçici olarak durdurulan ve zaman içinde ülkeye kendi çabası ile entegre olan kişilerin ülkede kalması da kolaylaştırılmış olmaktadır. Dolayısıyla, söz konusu statü şartları tam olarak sağlayamayan sığınmacılar ve devlet için hem iç siyaset hem de dış politika açısından bir araç olmaktadır. "Belirsiz" ve "güvensiz" (Tize, 2020) tolerans statüsü nitelikli, eğitimli, iş piyasasına entegre olanlar için ülke politikaları ve ihtiyaçlar çerçevesinde "kalıcılığa dönüştürülebilir" ve zaman içinde vatandaşlıkla da sonuçlanabilen bir hale gelmiştir.

\section{Açık Kapı Politikası ve "Hak Edenlerin” Entegrasyonu}

2015 yılında Avrupa ülkeleri Suriyeli sığınmacı-mülteci krizi ile karşı karşıya kalmıştır. Sığınmacı-mülteci akımı karşısında ülkeler farklı uygulamalar yaparken, Angela Merkel "açık kapı politikası" uygulanacağını ve Suriye, Irak ve Afganistan'daki “olağandışı" koşullar nedeniyle Federal Almanya'nın 1.000.000 mülteciyi alacağını açıklamıştır (Baume, 2017). Almanya'nın 2015 yılında yaptı̆̆ bu açıklama sığınma politikası yoluyla ülkenin yumuşak güç algısını da iyileştirmiştir (Zoungrana, 2020: 103). Almanya'nın sığınmacı-mülteciler için hoş geldin yaklaşımı yalnızca Suriye'den değil başka ülkelerden de göçe yol açmıştır. Örneğin 2014 y1lı itibariyle alınan 202.834 yeni sığınma başvurusunun yaklaşık üçte biri sığınmacı olarak kabul edilmesi neredeyse imkansız olan Batı Balkan ülkelerinden gelen kişilerden oluşmakta olup, 2015 düzenlemesinin Arnavutluk, Kosova, Karadağ'1 güvenli üçüncü ülke olarak kabul etmesi de bu tür sığınmacı taleplerini azaltmayı amaçlamaktadır (Sökefeld, 2019: 97). Dolayısıyla, Suriyeli sığınmacıların hareketliliği Balkanlar'da ve diğer ülkelerde de sığınmacı-ekonomik amaçlı göçmen hareketine yol açmış olup, Almanya'da sınır dışı edilmelerin artması ve sığınmacılarla ilgili alınan önlemler de bu çerçevede şekillenmiştir.

Dublin prosedürlerinin durdurulması başka bir $\mathrm{AB}$ üyesi ülkeden gelseler dahi Suriyelilerin sığınmacı taleplerinin işleme alınacağı anlamına gelmektedir. Almanya'nın 2015 Ağustos-Ekim arasında Dublin prosedürlerini sadece Suriyeliler için durdurması ve 2015 Eylül ayından itibaren ise Avusturya ve Balkan güzergahı için sınır kontrollerini başlatması "sınırsız bir hoş geldin" olmadığını göstermektedir (Rietig \& Müller, 2016). $\mathrm{Bu}$ kapsamda, ilk olarak artan sığınmacı sayısı ile birlikte Ekim 2015'te sığınma süreçlerini hızlandırmak amacıyla sığınma kararlarına ilişkin şikayet sürecini kısaltan, Arnavutluk, Kosova ve Karadağ' ${ }_{1}$ "güvenli köken ülke" kabul eden bir yasa (Asylverfahrensbeschleunigungsgesetz, Asylum Act) kabul edilmiştir (Kirchhoff \& Lorenz, 2018: 59). Diğer taraftan, aile birleşimi ile ilgili artan talepler nedeniyle 2016 yılından itibaren daha önce otomatik olarak verdiği mülteci statülerini ek koruma statüsü ile değiştirmiş̧tir (Stevens, 2017: 187). Bu şekilde Almanya kalıcı mülteci statülerini geçici statülerle değiştirmeye ve yeni sığınmacı akımlarını durdurmaya çalışmıştır.

Sığınmacı sayısındaki artışla birlikte olumlu yaklaşım iç siyasetteki değişim, aşırı sağın yükselişi gibi nedenlerle hemen değişmeye başlamıştır. Betts'e göre (2009: 29) analitik liberalizm zorunlu göçte iç siyasetin önemini göstermekte olup, "İç siyaset devletlerin mülteci ve diğer zorunlu göçmenlere yönelik cevaplarını önemli derecede etkilemektedir" ve 1990'lı yıllardaki sığınmacı krizinde iç siyaset, seçimler, kampanyalar ve medya göçün politikleşmesiyle mültecilere karşs tepkiye yol açmıştır. 
Benzer bir durum 2015 yılında Almanya'nın mültecilere karşı "hoş geldin” yaklaşımının da hızlı bir biçimde değişmesinde kendini göstermektedir. "Batı'nın İslamlaşmasına Karşı Vatansever Avrupalılar" (PEGIDA) ve Almanya için Alternatif (AfD) adlı partilerin yükselişi ve faaliyetleri mültecilere yönelik yaklaşımın değişmesine, kamuoyunun baskısının artmasına yol açmışıtır (Rietig \& Müller, 2016). Almanya'nın alması gereken mülteci sayısı, mültecilerin Alman kültürel kimliğine tehdit olup olmadığ 1 , entegrasyon programlarının maliyeti, $\mathrm{AB}$ yardımlarının ülkeler arasında oransal dağılımı gibi hususlar tartışma noktalarından bir kısmını oluşturmuştur (Funk, 2016). Dolayısıyla, Almanya'nın mültecilere "hoş geldin" politikası çok kısa bir zaman içinde yerini bir taraftan sığınmacı sayısını azaltmaya diğer taraftan ise entegrasyonu ve özellikle iş piyasasına erişimi sağlayarak yükü azaltmaya, iç siyaseti dengelemeye yönelik politikalara dönüşmüştür. 2015 yılından 2019 yılına kadar kabul edilen kapsayıc1 düzenlemelerle bir taraftan entegrasyon politikaları güçlendirilirken, diğer taraftan tolerans statüsünde olanların da entegrasyonuna yönelik değişiklikler yapılmıştır.

Betts'e göre "tüm devletler zorunlu göçmenlere karşı aynı şekilde davranmamakta", "devletlerin karakteri”, tarihte mültecilere karşı cömert olup olmadıkları zorunlu göçe verdikleri tepkiyi etkilemektedir (Betts, 2009: 29). Sadece Almanya değil başka bazı ülkelerde de nüfus yaşlanmakta ve nitelikli iş gücü ihtiyacı bulunmakta olup, Almanya'nın özellikle II. Dünya savaşı sonrası etnik Almanları kabulüne ilişkin tarihten gelen mülteci tecrübesinin Suriyeli mültecileri kabulünde etkili olduğu da söylenebilir (Bird, 2015). Diğer taraftan, Almanya'nın 1960'lı yıllardaki göçmenin geçiciliğine dayanan "misafir işçi" tecrübesi gönüllü göçmenlerin bile köken ülkeye geri dönmediğini ve entegrasyon sorunların göstermiş olup, zorunlu olarak göç eden ve halihazırda ülkelerine geri dönmeleri mümkün olmayan mültecilerin entegrasyonunun gerekliliğini ortaya koymaktadır.

Almanya 1990'lı yıllardaki sığınmacıların iş piyasasına erişimini engelleyen yaklaşımdan sığınmacıların bir an önce iş piyasasına erişimi ve entegrasyonunu amaçlayan yaklaşıma geçiş yapmış ve yaşlanan nüfus, nitelikli iş gücü ihtiyacı, sığınmacıların orta ve uzun dönemde Almanya'da yerleşebilecekleri gerçeği bu yaklaşım değişimini getirmiştir (Rietig, 2016: 3-4). Almanya, misafir işçi politikasından entegrasyon siyasetine geçiş yapmış olup, 2015 yllından itibaren mülteciler için "hak edenlerin" (Bleibeperspektive-good prospects to stay) entegrasyon kursları ve dil eğitimleri ile desteklenmesine dayanan bir yaklaşım benimsemiştir (Sökefeld, 2019: 9899). $\mathrm{Bu}$ durum ülkelerin ekonomik saiklerle mülteci kabul kotalarını belirledikleri (Stokes, 2019: 21) görüşünü de destekler niteliktedir. "Entegrasyon kuramın muhtelif yorumlarına imkan veren baskın kültürel ve politik hassasiyetleri yansitır" (Strang \& Ager, 2010: 592) ve "Anlamı ülkeden ülkeye, zaman içinde, çıarlar, değerler ve ilgili kişilerinin bakış açılarına bağlı olarak değişir” (Castles vd., 2002: 112). Entegrasyon politikaları federal düzeyde belirlenmekle birlikte, çeşitli belediyeler kendi çerçevelerini oluşturmuş ve yerel düzeyde Berlin (2010), Kuzey Ren Westfalya (2012) ve Baden Wurttemberg (2015) olmak üzere üç eyalet ise ayrıca entegrasyon yasaları kabul etmiştir 
(Hanewinkel \& Oltmer, 2018). Bu çerçevede Alman entegrasyon yaklaşımı da "hak edenlerin" entegrasyonu ve "hak etmeyenlerin" ise entegrasyon politikalarından dışlanmasına dayanmaktadır.

2016 yılında kabul edilen Entegrasyon Yasası (Integration Act-Integrationsgesetz) ile entegrasyon dersleri, şartlı mesleki eğitim, sığınma başvurusu sonucunu bekleyen 100.000 kişiye iş programları, iş piyasası öncelik kontrollerinin ${ }^{5}$ belirli bölgelerde sığınmacı ve sınır dışı edilmesi ertelenenler için kaldırılması, mülteciler ve ek koruma verilenler için ikamet yerinin belirlenmesi, A2 düzeyinde Almanca öğrenme ve geçimini sağlayabilme şartıyla 5 yılı dolduranlara sürekli ikamet izni verilmesi kabul edilmiştir (Gesley, 2016). Diğer taraftan, entegrasyon derslerine ve eğitimlere devamlılı̆̆ sağlamak amacıyla bazı önlemler de alınmıştır. Üniversiteye devam etme, mesleki eğitim veya düzenli bir işe sahip olma gibi geçerli mazereti olmadığı halde entegrasyon derslerine, mesleki eğitime ve iş programlarına katılmayan sığınmacıların aldıkları sosyal yardımlar azaltılacaktır (Rietig, 2016; Rietig \& Müller, 2016). 2016'da kabul edilen yasanın diğer bir özelliği entegrasyon kursları gibi eğitimlere yalnızca mülteci, sığınmacı ve ek koruma statüsünde olanların değil aynı zamanda tolerans statüsünde olanların da katılmasına izin verilmesi ve bekleme süresinin 3 aydan 6 haftaya düşürülmüş olmasıdır (Konle-Seidl, 2018: 33). Zoungrana (2020: 91) 1970’li yıllara kadar olan Almanya'nın göç politikalarının ekonomik, 1980 yılı sonrası insani politikaların bir sonucu olduğunu ve 2015 yılında yaşanan mülteci krizi sonrası yapılan düzenlemelere rağmen bu iki politika arasında karmaşıklı̆ın sona ermediğini belirtmektedir.

Federal İçişleri Bakanlığı Temmuz 2018'de göç, mülteciler ve sığınma politikasında düzenlemeleri içeren bir plan açıklamıştır. Söz konusu düzenlemede refah devletinin sağlayacağı imkanların göçü teşvik etmemesi, sığınmacıların sığınma sürecine girmeleri, suç işlememeleri ve kimliklerini gizlememeleri, Almanya'nın nitelikli ve eğitimli kişilere ihtiyacı olduğu ve göçün yönetiminde bu kuralların hakim olacağı, entegrasyonun ülkeye giren herkes için değil kalmalarına izin verilenler için uygulanacağı, sı ğınma talebi reddedilenlerin ülkeye terk etmesi gerektiği ve 2015 yılındaki gibi bir akışa izin verilmeyeceği belirtilmektedir (The Migration Master Plan, 2018). Bu plan açıkça entegrasyon siyaseti ile göçün yönetiminde nitelikli-eğitimli göçünün istendiğini ortaya koymakta olup, daha sonra yapılan düzenlemeler tolerans statüsünde olanlar için de bu kriterlerin geçerli olduğunu göstermektedir.

7 Haziran 2019'da kabul edilen göç yasa paketi tolerans statüsünün kullanım alanlarını artııırken sığınmacıları olumsuz etkileyecek düzenlemeler de içermektedir. Düzenleme, sınır dışı edilmesi gerekirken geçerli mazereti olmadan görüşmeye gelmeyen kişilerin hapishanelerde tutuklanması, sosyal yardımların sadece 2 hafta verilmesi, yetkililere statüleri azaltma ve sosyal yardımlar ile iş piyasasına erişimin

\footnotetext{
5 İş piyasası öncelik kontrolü: Federal İş Bulma Ajansı bir yabancıya iş vermeden önce iş piyasasında öncelik kontrolü yapar. Yabancı çalıştırmanın Alman iş piyasasını olumsuz etkileyip etkilemeyeceği, Alman vatandaşı, Alman çalışanlarla aynı yasal statüye sahip iş piyasasına tercihli erişim hakkına sahip diğer yabancılar karşılaştırılır (Gesley, 2016, Ağustos 15).
} 
sınırlanması yetkisini vermektedir (Koop, 2019). Değişiklikler 2015 ve 2017 yıllarındaki mültecileri de kapsamakta olup, çoğunluğu Suriyeli olmak üzere Afganistan, Irak, Eritre gibi ülkelerden yaklaşık 600.000 kişi bu kapsamda yer almakta ve Federal Göç ve Mülteciler Kurumu'na $(B A M F)$ mültecilerin statüsünü feshedebilme yetkisi verilmektedir. Tolerans statüsünde bulunan kişi sayısı ise yaklaşık 235.000'dir (Koop, 2019). Düzenleme ile "devlet sırrı" sayılacak konular genişletilmiş, sınır dışı edilme, elçilik ve doktor randevuları devlet sırrı kapsamına alındığından sığınmacılara danışmanlık sunan sivil toplum kuruluşlarının "yardım ve suç ortaklığı” ile suçlanması mümkün hale gelmiştir (Koop, 2019). Federal Alman Hükümeti yaklaşımı açısından sınır dışı etme egemenliğin korunması için önemli hale gelmiş ve Afganistan gibi ülkeler bu amaçla bazı bölgeleri açısından güvenli kabul edilmiştir (Sökefeld, 2019: 93). Tartışmalı paketle birlikte sınır dışı etmelerin artması beklenmekle birlikte 2020 yılındaki salgın sınır dışı etmelerin ertelenmesine yol açmıştır.

Yasayla çalışanlar ve eğitim alanlar için ülkede kalma sürelerini uzatan eğitim ve çalışma Duldung'u olarak adlandırılan tolerans kriterleri belirlenmiştir. Eğitim toleransı, bakım hizmetlerine ilişkin iş gücü ihtiyacını karşılamak amacıyla bu alanda eğitim alanları kapsamakta ve tolerans statüsünde olan kişilerin eğitimlerini tamamladıktan sonra doğrudan işe başlamaları halinde 2 yıllık ikamet izni alabilmelerini içermektedir (European Asylum Support Office, 2020: 176). Çalışma toleransı ise ülkeye 1 Ağustos 2018'den önce girmiş, en az 12 aydır tolerans statüsünde olan, kimliği belirli, en az 18 aydır haftada 35 saat çalışan (tek ebeveynler için 20 saat), kendi ihtiyaçlarını karşılayacak gelire sahip, dil yeterliliğini ispatlayabilen, suça karışmamış, terörist organizasyonlarla ilişkisi olmayan, entegrasyon kursunu tamamlamış sığınmacılara 30 ay çalışma ülkede kalma izni vermektedir (Gesetz über Duldung bei Ausbildung und Beschaftigung, 2019). Söz konusu düzenlemenin genel olarak iş gücü piyasasının ihtiyaçlarını karşılamaya yönelik olduğu görülmektedir.

Sınırların korunması ve ülkeye girecek kişilerin belirlenmesi devletlerin egemenlik alanıdır. Kant'ın misafirperverlik tanımı yabancıların başka bir ülkeye girişinde düşmanca karşılanmaması üzerine odaklanmakla birlikte bu durumun kişilere "geçici misafirlik" hakkı verdiği ve bunun "sürekli kalma" hakkı sağlamadığı vurgulanmaktadır (Kant, 1795). Almanya 2015 yılındaki "hoş geldin” politikasını takip eden dönemde aldığı önlemlerle mülteci statüsü verdiği kişilerin statülerini değiştirerek ve iptal yetkisini alarak verilen sürekli kalma hakkının ülkenin egemenlik alanında değiştirilebileceğini göstermiştir. Yardımların azaltılması, süre kısıtı getirilmesi, suç işlememe, kimliği gizlememe gibi kriterler ise Almanya'nın refah devleti imkanlarından yararlanmak için sığınma yolunu kullanmak isteyenleri önleyici ve kamu güvenliğini sağlamayı hedeflemektedir. Kabul edilen göç planı ile getirilen eğitimli ve niteliklilerin göçüne ilişkin politikalar ise entegrasyon siyaseti ile ekonomik gerekliliklerin bir sonucu olarak karşımıza çıkmaktadır (Şekil 1). 


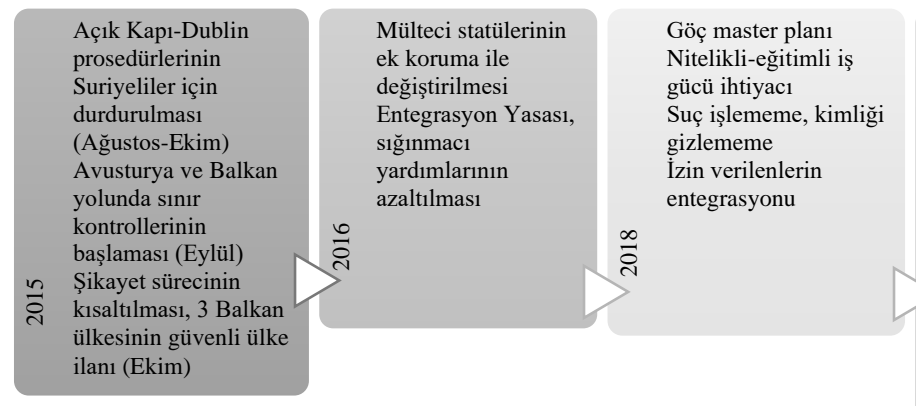

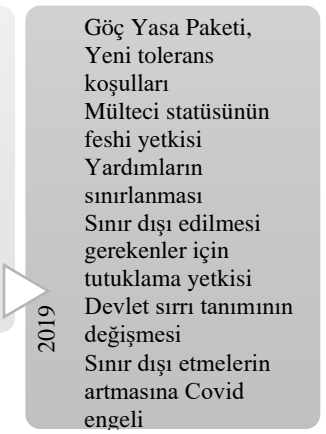

Şekil 1: 2015 yılından itibaren sığınmacı sayısının kontrolüne yönelik uygulamalar

Ayrıca, Almanya "geçici misafirlik" hakkını tolerans statüsü ile bir anlamda genişletmiş ancak sürekli kalma hakkı vermeyi çeşitli kriterlere bağlamıştır. Tolerans statüsünde yer alanların hak etmesi-entegrasyonu sonucunda "sürekli kalma" hakkının verilmesi egemen devletin belirlediği koşullara uymakla sağlanmakta olup, bu koşullar entegre olma şeklinde karşımıza çıkmaktadır. Dolayısıyla, sürekli kalma hakkı da aslında entegre olanların tolerans statüsünde olsalar dahi belirli süreler sonunda vatandaşlık almaları ile desteklenmektedir. Böylece Almanya göç politikasında hakim yaklaşım entegrasyon siyaseti ile ekonomik gereklilikler olarak karşımıza çıkmaktadır. Bu çerçevede tolerans statüsünde yer almak özellikle eğitimli, meslek sahibi, çalışma potansiyeli yüksek nitelikli gruplar için belirsizliği taşımakla birlikte nihai bir statü olmayıp dönüştürülebilir bir statü haline gelmiş̧tir. Almanya'nın düzenlemelerle açıkça "entegrasyon siyasetini” benimsediği ve sığınma sisteminde de bunu esas aldığ görülmekle birlikte Suriye için tanınan sınır dışı etmenin ertelenmesi uygulaması (İkamet Yasası 60a- Belirli ülkelerden gelen yabancılar için sınır dışı etme askıya alınabilir) diğer ülkelerden gelen sığınmacılar için söz konusu değildir. Sökefeld (2019) çalışmasında Almanya'nın sı̆̆ınma politikasının Afganlar açısından daha sınırlı olduğu, Suriyelilere tanınan imkanların tanınmadığını belirtmektedir. Dolayısıyla, her ne kadar hakim yaklaşım entegrasyon ve "hak etme" olsa da köken ülke itibariyle sığınmacılara tanınan imkanlar da farklılaşabilmektedir.

\section{Sonuç}

Almanya sığınma sistemi 1949 yılında kabul edilen Anayasa ile birlikte, tarihsel sığınmacı akımları ve daha sonra $\mathrm{AB}$ düzenlemelerinin de etkisi ile gelişmiş olup, temelde mülteci, sığınmacı, ek koruma ve sınır dışı edilmenin yasaklanması-ertelenmesi (Toleration-Duldung) olmak üzere dört grup koruma üzerine kurulmuştur. Bu makale, Alman sığınma sisteminde 2015 mülteci krizi ile birlikte artan sığınmacı sayısını sınırlama amacıyla alınan önlemlerin çerçevesini oluşturmayı, entegrasyon yaklaşımı ve tolerans statüsüne ilişkin bu dönemde gerçekleşen değişimi incelemeyi amaçlamıştır. 
1949 Federal Alman Anayasası siyasi mültecilere sığınma hakkı vererek bu konuda öncü olmuştur. 1949 yılından itibaren hemen hemen her 10 yılda bir yeni bir sığınmacı veya göçmen dalgası ile karşılaşan Almanya genellikle etnik Almanların göçü ile karşılaşırken, 1960'lı yıllardaki "misafir işçilerle” birlikte Avrupa dışından göçmenlerle de karşılaşmaya başlamıştır. Ekonomik göçmenlerin geçici olmasına ilişkin yaklaşım daha sonra bu grubun entegrasyonu sorununu ortaya çıkarmıştır. Hallstein Doktrini çerçevesinde Doğu Almanya ve tanıdığı ülkelerle diplomatik ilişki kurulamadığından mülteci olma şartlarına sahip olmayan kişileri sınır dışı edemeyen Almanya bu kişileri sistem içinde "tolere" etmek zorunda kalmıştır.

Bu çerçevede, tolerans statüsü özellikle 1990'lı yıllarda Bosnalı sığınmacılar için de kullanılan geçici, ülkede sürekli kalma izni vermeyen, belirsiz bir statü olup, bu statüde yıllarca kalan kişiler bulunmaktadır. Söz konusu statü başlangıçta yardım alma, iş piyasasına erişme imkanı vermeyen bir statü olmakla birlikte zaman içinde değişmiş ve belirli süre bu statüde kalanların yardım alması, çalışması gibi hususlar kabul edilmiştir. 2005 y1lından itibaren ülkenin göçmen ülkesi olduğu kabul edilerek entegrasyona ilişkin yasal düzenlemeler yapılmaya başlanmıştır. 2015 yılında Almanya'nın 1 milyon mülteci alacağını açıklaması ile başlayan "hoş geldin" yaklaşımı sınırsız bir hoş geldin olmayıp, sığınmacı sayısının hızla artması sonucunda birkaç ay içinde sınırlayıcı politikalara dönüşmeye başlamıştır. Ancak, bu hızla değişimimde ülkenin iç siyaseti, mülteci yükü, aşırı sağın yükselişi yanı sıra "hoş geldin” yaklaşımının özellikle Balkan ülkeleri olmak üzere başka ülkelerden de sığınmacı-göçmen hareketine yol açması da etkili olmuştur.

2015 yılından itibaren Dublin prosedürlerinin Suriyeliler için durdurulması ile başlayan açık-kapı politikası Avusturya ve Balkan yolunda sınır kontrollerinin başlatılması, sığınmacıların şikayet sürelerinin kısaltılması, 3 Balkan ülkesinin güvenli ülke ilan edilmesi, mülteci statülerinin başka statülerle değiştirilmesi, entegrasyon yasası çıkarılması ve sığınmacı yardımlarının azaltılması, göç master planı hazırlanarak nitelikli-eğitimli göçünün teşviki, izin verilenlerin entegrasyonu, suç işlememe ve kimliğini gizlememe kriteri getirilmesi, yeni tolerans kriterlerinin kabulü, mülteci statüsünün feshi yetkisi, yardımların süreyle sınırlanması, tutuklama yetkisi, devlet sırrı tanımının genişletilmesi ve sınır dışı etmelerin artmasına yönelik önlemlerle sürmüştür. Söz konusu önlemler tolerans statüsünde de değişiklikler getirmiş, bu statüdekilere entegrasyon derslerine erişme ve belirli şartlarla çalışma imkanının tanınması yoluyla entegre olma imkanı sunulmuştur. Düzenlemelerde hakim olan yaklaşım suç işlememe gibi kriterlerle birlikte "hak etme" olup, eğitim ve çalışma hak etmenin göstergesi olarak kullanılmaktadır. Dolayısıyla, yeni yaklaşımda tolerans statüsünde olanlar dahil "hak ettiklerini” eğitime devam etmek, çalışmak, dil öğrenmek gibi yollarla gösterebiliyorsa kalıcı statülere ulaşarak ülkede yerleşimleri yasal hale gelebilmektedir. Bu durumda geçici ve belirsiz bir statü olan tolerans statüsünde olan nitelikli, eğitimli, mesleği olan, çalışma imkanı bulan sığınmacıların ülkeye yerleşmesi yasal olarak mümkün hale gelmiş bulunmakta ve statünün barındırdığı entegrasyonu engelleme riski de ortadan kalkmaktadır. Ancak, tolerans statüsünde olanlar için belirsizlik ve sınır dışı edilme riski 
sürmesine rağmen entegrasyon kapsamına alınmaları "hak edenlerin" ülkede yerleşmelerini sağlayacak bir yöntem olarak karşımıza çıkmaktadır.

Sonuç olarak, Federal Alman sığınma sisteminde 2015 sonrası alınan önlemler kademe kademe mülteci statüsü almayı ve o statüde kalmayı güçleştirmiş, entegrasyon siyaseti ve ekonomik gereklilikler hem sığınma hem de göç siteminde hakim olmuştur. Tolerans statüsü hala belirsiz-geçici bir statü olmasına rağmen insani yaklaşım açısından sığınmacılara geçici de olsa ülkede kalma ve eğitime devam etme, dil öğrenme, çalışma gibi göstergelerle "hak ettiklerini" ispatlamaları halinde ülkede kalmaya izin veren entegrasyon siyasetine uygun ve dönüştürülebilir bir statü haline gelmiştir.

\section{Kaynaklar}

Abraham, D. (2016). From migration crisis to immigration and integration regime. University of Miami Legal Studies. https://papers.ssrn.com/sol3/papers.cfm?abstract_id=2746659

Baume, M. de L. (2017, Ağustos 27). Angela Merkel defends open border migration policy. POLITICO. https://www.politico.eu/article/angela-merkel-defends-openborder-migration-refugee-policy-germany/

Betts, A. (2009). Forced migration and global politics. Wiley Blackwell Publication.

Bierbach, M. (2018, Nisan 4). A brief history of refugees who escaped to Germany. InfoMigrants. https://www.infomigrants.net/en/post/8463/a-brief-history-ofrefugees-who-escaped-to-germany

Bird, M. (2015, Eylül 9). Germany's history explains why it's so accepting of refugeesAnd why it wants austerity for Greece. Business Insider. https://www.businessinsider.com/germanys-history-explains-why-its-so-acceptingof-refugees-and-why-it-wants-austerity-for-greece-2015-9

Bundesministerium des Innern, für Bau und Heimat (2020). Abschiebungen und ausreisen im ersten halbjahr 2020 (Drucksache 19/21149). https://www.bundestag.de/presse/hib/707192-707192

Gesetz über Duldung bei Ausbildung und Beschaftigung, Bundesgesetzblatt Jahrgang 2019 Teil Nr.26 2019). https://www.bgbl.de/xaver/bgbl/media/5B2B066D608FF657777F7A1F6FD2183B/ bgbl119s1021_77668.pdf

Bunyan, T. (1997). Key texts on Justice and Home Affairs in the European Union: 19761993 Vol 1. Statewatch

Castles, S., Korac, M., Vasta, E., \& Vertovec, S. (2002). Integration: Mapping the field (Home Office Online Report Sy 29/3). Home Office. https://webarchive.nationalarchives.gov.uk/20110218135832/http:/rds.homeoffice.g ov.uk/rds/pdfs2/rdsolr2803.doc 
Dimova, R. (2006). From protection to ordeal: Duldung status and Bosnians in Berlin (Working Paper No:87). Max Planck Institute for Social Anthropology. https://pure. mpg. De/pubman/faces/ViewItemOverviewPage. jsp?itemId=item_922942_3

EMN. (2016). Approaches to rejected asylum seekers in Germany (Working Paper 69). Federal Office for Migration and Refugees. https://ec. europa. eu/homeaffairs/sites/homeaffairs/files/what-we-

do/networks/european_migration_network/reports/docs/emn-studies/emn-studies11a_germany_rejected_asylum_seekers_en.pdf

EMN. (2018). Asylum and migration glossary 6.0: A tool for better comparability produced by the European Migration Network. European Commission. https://ec. europa. eu/home-affairs/sites/homeaffairs/files/what-wedo/networks/european_migration_network/docs/interactive_glossary_6.0_final_ver sion. pdf

European Asylum Support Office. (2020). EASO asylum report 2020: Annual report on the situation of asylum in the European Union. https://data. europa. eu/doi/10.2847/531878

European Migration Network. (2010). Organisation of asylum and migration policies in the EU Member States. https://ec. europa. eu/homeaffairs/sites/homeaffairs/files/what-wedo/networks/european_migration_network/reports/docs/emn-studies/migrationpolicies/00._emn_synthesis_report_organisation_of_asylum_and_migration_policie s_august_2010_en.pdf

Federal Ministry of the Interior, Building and Community. (2018, Temmuz 10). The Migration Master Plan. http://www.bmi.bund.de/SharedDocs/kurzmeldungen/EN/2018/07/masterplan.html; jsessionid=24DF55E49D648029D4A53EFBA7A7B5AB.1_cid287?nn=9919724

Federal Office for Migration and Refugees. (2015). Migration, integration, asylum: Political developments in Germany 2014. European Migration Network. https://www.bamf.de/SharedDocs/Anlagen/EN/EMN/Politikberichte/emnpolitikbericht-2014-germany.pdf?_blob=publicationFile \&v=6

Federal Office for Migration and Refugees. (2019). The stages of the German asylum procedure: An overview of the individual procedural steps and the legal basis. https://www.bamf.de/SharedDocs/Anlagen/EN/AsylFluechtlingsschutz/Asylverfahr en/das-deutsche-asylverfahren.pdf?_blob=publicationFile \&v=12

Federal Statistical Office. (2020, Temmuz 28). Current population. https://www.destatis.de/EN/Themes/Society-Environment/Population/CurrentPopulation/_node.html 
Funk, N. (2016). A spectre in Germany: Refugees, a 'Welcome Culture' and an 'Integration Politics'. Journal of Global Ethics, 12(3), 289-299. https://doi/full/10.1080/17449626.2016.1252785.

Gesley, J. (2016, Ağustos 15). Germany: Act to integrate refugees enters into force. Global Legal Monitor. https://www.loc.gov/item/global-legal-monitor/2016-0815/germany-act-to-integrate-refugees-enters-into-force/

Gesley, J. (2017). Germany: The Development of migration and citizenship law in postwar Germany. The Law Library of Congress, Global Research Center. https://www.loc.gov/law/help/migration-citizenship/germany.php

Gräßler, B. (2005, Ocak 1). First German immigration law takes effect Deutsche Welle. https://www.dw.com/en/first-german-immigration-law-takes-effect/a-1442681

Handbook Germany. (2020a). Duldung. https://handbookgermany.de/tr/rightslaws/asylum/duldung.html

Handbook Germany. (2020b). Rejected asylum. https://handbookgermany. De/en/rightslaws/asylum/rejected-asylum. html

Hanewinkel, V., \& Oltmer, J. (2018, Ocak 12). Refuge and Asylum in Germany. Bundeszentrale für politische Bildung. https://www.bpb.de/gesellschaft/migration/laenderprofile/262813/refuge-andasylum-in-germany

IOM. (2004). International migration law: Glossary on migration. https://publications. iom. int/system/files/pdf/iml_34_glossary.pdf

Kant, I. (1795). Perpetual peace: A Philosophical Sketch. http://fs2.american.edu/dfagel/www/Class\%20Readings/Kant/Immanuel\%20Kant, \%20_Perpetual\%20Peace_.pdf

Karakoç Dora, Z. (2020). Doğu Avrupa'nın din merkezli göçmen politikaları. Hitit Üniversitesi Illahiyat Fakültesi Dergisi-Journal of Divinity Faculty of Hitit University, 19(1), 35-62. https://doi.org/10.14395/hititilahiyat.705788

Kirchhoff, M., \& Lorenz, D. (2018). Between illegalization, toleration and recognition: Contested asylum and deportation policies in Germany. İçinde S. Rosenberger, V. Stern, \& N. Merhaut (Eds.), Protest movements in asylum and deportation (ss.4968). Springer International Publishing.

Konle-Seidl, R. (2018). Integration of refugees in Austria, Germany and Sweden: Comparative analysis. European Parliament.https://www.europarl.europa.eu/RegData/etudes/STUD/2018/614200/IP OL_STU(2018)614200_EN.pdf

Koop, K. (2019). Op-ed: Detention, insecurity, rights deprivation-The legal crackdown on asylum seekers in Germany. European Council on Refugees and Exiles Weekly Bulletin. https://www.ecre.org/detention-insecurity-rights-deprivation-the-legalcrackdown-on-asylum-seekers-in-germany/ 
Korntheuer, A. (2017). Germany's refugee protection sytem. İçinde A. Korntheuer, P. Pritchard, \& D. B. Maehler (Eds.), Structural context of refugee integration in Canada and Germany (ss. 37-41). GESIS, Leibniz Institut für Sozialwissenschaften.

Leise, E. (2007, Nisan 5). Germany to regularize "Tolerated" asylum seekers. The Online Journal of the Migration Policy Institute. https://www.migrationpolicy.org/article/germany-regularize-tolerated-asylumseekers

Council Directive 2001/55/EC, (2001). https://eur-lex. europa. eu/legalcontent/EN/TXT/?uri=CELEX\%3A32001L0055

Oltmer, J. (2016). Germany and global refugees: A history of the Present. CESifo DICE Report, Ifo Institut-Leibniz-Institut Für Wirtschaftsforschung an der Universität München, München, 14(4), 26-31.

Poutrus, P. G. (2014). Asylum in postwar Germany: Refugee admission policies and their practical implementation in the Federal Republic and the GDR between the late $1940 \mathrm{~s}$ and the mid-1970s. Journal of Contemporary History, 49(1), 115-133. https://doi:10.1177/0022009413505667

Rietig, V. (2016). Moving beyond crisis: Germany's new approaches to integrating refugees into the labor market. Migration Policy Institute. https://www.migrationpolicy.org/research/moving-beyond-crisis-germany-newapproaches-integrating-refugees-labor-market

Rietig, V., \& Müller, A. (2016). The new Reality: Germany adapts to its role as a major migrant magnet. Migrationpolicy. https://www.migrationpolicy.org/article/newreality-germany-adapts-its-role-major-migrant-magnet

Sökefeld, M. (2019). Nations rebound: German politics of deporting Afghans. IQAS, 50(1-2), 91-118. https://doi:10.11588/iqas.2019.1-2.10341

Stevens, D. (2017). Asylum, refugee protection and the European response to Syrian migration". Journal of Human Rights Practice, 9(2), 184-189. https://doi: 10.1093/jhuman/hux016

Stokes, L. (2019). The permanent refugee crisis in the Federal Republic of Germany, 1949. Central European History, 52(1), 19-44. https://doi: $10.1017 /$ S0008938919000025

Strang, A., \& Ager, A. (2010). Refugee integration: Emerging trends and remaining agendas". Journal of Refugee Studies, 23(4), 589-607. https://doi:10.1093/jrs/feq046

Tize, C. (2020). Living in permanent temporariness: The multigenerational ordeal of living under Germany's toleration status". Journal of Refugee Studies, fez119. https://doi:10.1093/jrs/fez119 
UNHCR. (2010). Convention and Protokol Relating to the Status of Refugees. https://www.unhcr.org/protection/basic/3b66c2aa10/convention-protocol-relatingstatus-refugees.html

UNHCR. (2020). Global trends: Forced displacement in 2019. https://www.unhcr.org/flagship-reports/globaltrends/globaltrends2019/

United Nations, Department of Economic and Social Affairs Population Division. (2019). International migration 2019: Report (ST/ESA/SER. A/438). https://www.un.org/en/development/desa/population/migration/publications/migrati onreport/docs/InternationalMigration2019_Report.pdf

Universal Declaration of Human Rights. (1948). https://www.un.org/en/universaldeclaration-human-rights/

Üstün, M. T. (2021). Göçün güvenlikleştirilmesi ve FRONTEX operasyonları. İçinde İ. Kalaycı ve G. Kalmış (Eds.), Çağlar boyu göç (tarih-kültür-medeniyet) (379-400). Gazi Kitabevi.

Zetter, R. (2007). More labels, fewer refugees: Remaking the refugee label in an era of globalization. Journal of Refugee Studies, 20(2), 172-192. https://doi:10.1093/jrs/fem011

Zoungrana, W. (2020). No country for migrants? Critical perspectives on asylum, immigration, and integration in Germany. BRILL. 